\title{
Pengaruh Pembangunan Kawasan Ekonomi Khusus Sorong Terhadap Pertumbuhan Ekonomi Provinsi Papua Barat
}

\section{The Influence of the Development of the Special Economic Zone in Sorong on the Economic Growth of West Papua Province}

\author{
Teguh Syali ${ }^{1}$, A. Muhibuddin² ${ }^{2}$ Haeruddin Saleh ${ }^{2}$ \\ 1 Magister Perencanaan Wilayah dan Kota Program Pascasarjana Universitas Bosowa \\ ${ }^{2}$ Program Studi Perencanaan Wilayah dan Kota, Program Pascasarjana, Universitas Bosowa \\ E-mail: teguh.syali89@gmail.com
}

Diterima: 20 Juli 2020/Disetujui 07 Desember 2020

\begin{abstract}
Abstrak. Sorong merupakan kota yang sangat strategis karena merupakan pintu masuk dan persinggahan provinsi papua. Sorong juga dikenal sebagai kota perdagangan dan industri jasa karena dikelilingi oleh kawasan kabupaten sumber daya alam yang sangat potensial yang dapat membuka peluang investasi dalam dan luar negeri. Kawasan Ekonomi Khusus (KEK) adalah kawasan dengan batas tertentu untuk melaksanakan fungsi perekonomian dan memperoleh fasilitas tertentu. Kawasan tersebut disiapkan untuk memaksimalkan kegiatan industri, ekspor, impor, dan kegiatan ekonomi lainnya yang memiliki nilai ekonomi tinggi. KEK sorong yang terletak di Selat Sele memberikan keunggulan geoekonomi yaitu potensi di bidang perikanan dan transportasi laut. Lokasi ini juga sangat strategis untuk pengembangan industri logistik, agroindustri, dan pertambangan, sehingga KEK Sorong dikembangkan dengan kegiatan 3 potensi tersebut dan diprediksi dapat menghasilkan investasi sebesar Rp 32,2 triliun pada tahun 2025. Penelitian ini bertujuan untuk menguji dan menganalisis pengaruh KEK Sorong terhadap pertumbuhan ekonomi di Provinsi Papua Barat yang dianalisis menggunakan metode deskriptif kualitatif dan untuk mengetahui faktor-faktor signifikan yang mempengaruhi pertumbuhan ekonomi di Papua Barat dengan analisis regresi linier berganda. Variabel prediksi yang digunakan dalam penelitian ini adalah jasa (X1), industri (X2), tenaga kerja (X3), modal jasa (X4), perdagangan (X5), ekspor (X6) dan pertumbuhan ekonomi sebagai variabel Y. Hasil penelitian ini menunjukkan bahwa KEK sangat berpengaruh positif terhadap pertumbuhan ekonomi Provinsi Papua Barat.
\end{abstract}

Kata Kunci: Zona Ekonomi Khusus, Pertumbuhan Ekonomi, KEK, Papua Barat

\begin{abstract}
Sorong is a very strategic city because it is the doorway and stopover of papua province. Sorong is also well known as city of trade and services industry because it is surrounded by very potential natural resources districts areas that can open the opportunities for domestic and foreign investment. Special Economic Zones (SEZ) are areas with certain limits to carry out the economic functions and obtain certain facilities. Those areas are prepared to maximize industrial activities, export, import, and other economic activities that have high economic value. SEZ sorong which is located in the Sele Strait provides geo-economic advantages namely the potential in the fisheries and sea transportation sectors. This location is also very strategic for development of logistic industry, agroindustry, and mining, so that SEZ sorong was developed by the activities of those three potentials and predicted to be able produce investment of Rp 32.2 trillion in 2025. This study aims to examine and analyze the effect of SEZ Sorong on economic growth of West Papua Province which was analyzed using qualitative descriptive method and to identify significant factors that effecting economic growth in West Papua with multiple linear regression analysis. Predictive variables used in this study are service (X1), industry (X2), labor (X3), service capital (X4), trade (X5), Export (X6) and economic growth as variable Y. The result of this study shows that SEZ is very influential positively on the economic growth of West Papua Province.
\end{abstract}

Keywords: Special Economic Zones, Economic Growth, SEZ, West Papua

\section{Pendahuluan}

Pembangunan adalah semua Proses perubahan yang di lakukan melalui upaya-upaya secara sadar dan terencana (Riyadi dan Deddy Supriyadi,2005). Pembangunan ekonomi daerah adalah suatu proses dimana pemerintah daerah dan masyarakatnya mengelola sumberdaya yang ada dan membentuk suatu pola kemitraan antara pemerintah daerah dan swasta untuk menc iptakan suatu lapangan kerja baru dan merangsang perkembangan kegiatan ekonomi di wilayah tersebut. Pembangunan ekonomi daerah merupakan suatu proses yang mencakup pembentukan institusi-institusi baru, pembangunan industri-industri alternatif, perbaikan kapasitas tenaga kerja yang ada untuk menghasilkan produk dan jasa yang lebih baik, identifikasi pasar-pasar baru, alih ilmu pengetahuan dan pengembangan perusahaan-perusahaan (Arsyad, 1999).

Pembanguan harus di pandang sebagai suatau proses multidimensional yang mencakup berbagai perubahan mendasar atas struktur social,sikap - sikap masyarakat,dan 
institusi-institusi nasional,disamping da tetap mengejar ekselerasi pertumbuhan ekonomi,penanganan ketimpangan pendapatan serta pengentasan kemisknan.jadi pada hakekatnya pembangunan itu harus mencerminkan perubahan total suatu masyarakat atau penyesuaian system social secara keseluruhan, tanpa mengabaikan keragaman kebutuhan dasar dan keinginan individual maupun kelompok-kelompok social yang serba lebih baik,secara material maupun spriritual (Michael P.Todaro dan Stephen C.Smith,2004). Bahwa pembangunan nasional dapat pula diartikan sebagai transformasi ekonomi, sosial dan budaya secara sengaja melalui kebijakan dan strategi menuju arah yang diinginkan (Deddy T. Tikson, 2005).

Menurut Rogers Dan Shoemaker, 1985 pembangunan merupakan suatu jenis perubahan sosial yang mana terdapat berbagai ide baru yang diperkenalkan di sebuah sistem sosial yang bertujuan agar bisa menghasilkan pendapatan per kapita dan level kehidupan yang lebih baik dengan menggunakan metode produski yang lebih canggih dan organisasi sosial yang lebih terarah.

Sirojuzilam (2008) mendefinisikan pembangunan ekonomi adalah suatu proses yang bersifat multidimensional, yang melibatkan kepada perubahan besar, baik terhadap perubahan struktur ekonomi, perubahan sosial, mengurangi atau menghapuskan kemiskinan, mengurangi ketimpangan, dan pengangguran dalam konteks pertumbuhan ekonomi. Adisasmita (2008), pembangunan wilayah (regional) merupakan fungsi dari potensi sumber daya alam, tenaga kerja dan sumber daya manusia, investasi modal, prasarana dan sarana pembangunan, transportasi dan komunikasi, komposisi industri, teknologi, situasi ekonomi dan perdagangan antar wilayah, kemampuan pendanaan dan pembiayaan pembangunan daerah, kewirausahaan (kewiraswastaan), kelembagaan daerah dan lingkungan pembangunan secara luas. Hasil evaluasi secara keseluruhan menunjukkan, selain penanganan dominan action plan (hanya sebahagian real action), pilihan pendekatan penanganan juga masih banyak bersifat tunggal dan monoton, tidak terintegratif dan komprehensif dalam penyelesaian/ penuntasan akar masalah dan kebutuhan problem solving (Syamsiar et al, 2021).

Pertumbuhan ekonomi wilayah adalah pertambahan pendapatan masyarakat yang terjadi di wilayah tersebut, yaitu kenaikan seluruh nilai tambah yang terjadi di wilayah tersebut. Pertambahan pendapatan itu diukur dalam nilai rill, artinya diukur dalam harga konstan. Hal itu juga menggambarkan balas jasa bagi faktor-faktor produksi yang beroperasi di daerah tersebut. Kemakmuran suatu wilayah selain ditentukan oleh besarnya nilai tambah yang tercipta di wilayah tersebut juga oleh seberapa besar terjadi transfer payment yaitu bagian pendapatan yang mengalir ke luar wilayah atau mendapat aliran dana dari luar wilayah (Richardson, 1991). Menurut Sirojuzilam (2008) perbedaan pokok antara analisis pertumbuhan perekonomian nasional dan analisis pertumbuhan daerah adalah bahwa yang dititikberatkan dalam analisis tersebut belakangan adalah perpindahan faktor (factors movement). Kemungkinan masuk dan keluarnya arus perpindahan tenaga kerja dan modal menyebabkan terjadinya perbedaan tingkat pertumbuhan ekonomi regional. Perkembangan dan pertumbuhan ekonomi daerah akan lebih cepat apabila memiliki keuntungan absolute kaya akan sumber daya alam dan memiliki keuntungan komparatif apabila daerah tersebut lebih efisien dari daerah lain dalam melakukan kegiatan produksi dan perdagangan. Teori pertumbuhan ekonomi wilayah menganalisis suatu wilayah sebagai suatu sistem ekonomi terbuka yang berhubungan dengan wilayahwilayah lain melalui arus perpindahan faktor-faktor produksi dan pertukaran 19 komoditas. Pembangunan dalam suatu wilayah akan mempengaruhi pertumbuhan wilayah lain dalam bentuk permintaan sektor untuk wilayah lain yang akan mendorong pembangunan wilayah tersebut atau suatu pembangunan ekonomi dari wilayah lain akan mengurangi tingkat kegiatan ekonomi di suatu wilayah serta interrelasi. Pertumbuhan ekonomi wilayah adalah peningkatan volume variabel ekonomi dari suatu sub sistem spasial suatu bangsa atau negara dan juga dapat diartikan sebagai peningkatan kemakmuran suatu wilayah. Pertumbuhan yang terjadi dapat ditinjau dari peningkatan produksi sejumlah komoditas yang diperoleh suatu wilayah (Tarigan, 2004)

Sesuai dengan Visi Pembngunan Nasional Sebagaimana Tertuang Dalam Undang-Undang Nomor 17 Tahun 2007 Tentang Rencana Pembangunan Jangka Panjang Nasional Tahun 2005-2025,maka visi percepatan dan perluasan pembangunan ekonomi Indonesia adalah Mewujudkan Masyarakat Indonesia Yang Mandiri, Maju, Adil, dan Makmur. Untuk mewujudkan visi Indonesia Tahun 2025,harus di perlukan adanya suatu proses masterplan percepatan dan perluasan pembangunan ekonomi Indonesia yang memiliki arah yang jelas serta strategi yang tepat,focus,dan terukur maka pemerintah menetapkan peraturan presiden Republik Indonesia Nomor 32 Tahun 2011 tentang Masterplen Percepatan dan Perluasan Pembangunan Ekonomi Indonesia Tahun 20112025,yang kemudian di rubah menjadi Peraturan Presiden Nomor 48 Tahun 2014 Tentang Perubahan Atas Peraturan Presiden Nomor 32 Tahun 2011 Tentang Masterplen Percepatan dan Perluasan Pembngunan Ekonomi Indonesia Tahun 2011-2025.Pembngunan Ekonomi Indonesia Tahun 2011-2025

Kawasan Ekonomi Khusus (KEK) merupakan sala satu strategi pemerintah Indonesia dalam mewujudkan visi Pembangunan Nasional.Menurut Undang-Undang Nomor 39 Tahun 2009 Tentang Kawasan Ekonomi Khusus (KEK), Kawasan Ekonomi Khusus adalah Kawasan tertentu dimana diberlakukan ketentuan khusus di bidang Keperbankan,Perpajakan,Perijinan,Keimigrasian dan Ketenaga kerjaan.Maksud Pengembngan KEK adalah untuk memberi peluang bagi peningkatan investasi melalui penyiapan kawasan yang memiliki keunggulan dan siap menampung kegiatan industri,ekspor-impor,serta kegiatan ekonomi yang mempunyai nilai ekonomi tinggi.Indonesia akan berupaya menarik minat para investor untuk menanamkan modalnya di KEK dengan pemberian berbagai fasilitas khusus seperti pemberian kemudahan perizinan usaha, kelonggaran izin lingkungan, aturan, Perbankan, perpajakan dan pelayanan perdagangan.

Keseriusan Pemerintah membangun dan mengembangkan KEK di Indonesia adalah telah di di keluarakan Undang-Undang Nomor 39 Tahun 2009 tentang Kawasan Ekonomi Khusus,yang mengatur hal terkait dengan pembangunan KEK .Niat Pemerintah Menggarap KEK telah terlihat beberapa tahun sebelumnya dimana dalam satu pasal dalam Undang-Undang Nomor 25 Tahun 2007 telah di ataur mengenai Kawasan Ekonomi Khusus.Pembentukan Ekonomi Khusus (KEK) merupakan 
Program yang diinisiasi oleh pemerintah untuk mempercepat pertumbuhan ekonomi dengan mempertimbangkan aspek ruang atau wilayah titik tekannya terletak pada pemberian prioritas berupa perlakuan khusus pada kawasan tertentu untuk menjadi pusat pertumbuhan

Kondisi geografis Kota Sorong sangatlah strategis karena merupakan pintu keluar masuk Provinsi Papua dan Kota Persinggahan. Kota Sorong juga rnerupakan Kota industri, perdagangan dan jasa, karena Kota Sorong dikelilingi oleh Kabupaten - Kabupaten yang mempunyai Sumber Daya Alam yang sangat potensial sehingga membuka peluang bagi investor dalam maupun luar negeri untuk menanamkan modalnya. Berdasarkan letak geografisnya,wilayah penelitian yang di maksud berada pada Kota Sorong Provinsi Papua Barat. Secara Geografis Kota Sorong terletak pada posisi antara $131^{\circ} 15^{\prime}$ Bujur Timur dan $0^{\circ} 54^{\prime}$ Lintang Selatan dengan ketinggian 3 meter dari permukaan laut . Kota Sorong dengan luas wilayah $1.105 \mathrm{Km}^{2}$ terdiri dari 6 (enam ) Distrik dan 31 Kelurahan adalah pintu gerbang bagi Provinsi Papua Barat, disamping sebagai Kota persinggahan juga merupakan Kota industri, perdagangan dan jasa. Adapun luas Kota Sorong berdasarkan Luas Distrik (Kecamatan) adalah sebagai berikut: Sorong $(126,85 \mathrm{~km} 2)$, Sorong Barat (254,15 km2), Sorong Utara $(229,71 \mathrm{~km} 2)$, Sorong Timur (158,22 km2), Sorong Manoi (135,97 km2), Kepulauan Sorong $(200,10 \mathrm{~km} 2)$ Batas-batas administratif Kota Sorong Berdasarkan UU Nomor 45 Tahun 1999 Tentang Pembentukan Propinsi Irian Jaya Tengah, Propinsi Irian Jaya Barat, Kabupaten Paniai, Kabupaten Mimika, Kabupaten Puncak Jaya dan Kota Sorong ( Lembaran Negara RI Nomor 173 Tahun 1999 ), Tambahan Lembaran Negara RI Nomor 3894), adalah sebagai berikut : Sebelah Barat : Selat Dampir,Sebelah Utara : Distrik Makbon, Kabupaten Sorong dan Selat Dampir,Sebelah Timur : Distrik Makbon, Kabupaten Sorong,Sebelah Selatan : Distrik Aimas,Kabupaten Sorong dan Distrik Salawati, Kabupaten Raja Ampat.

\section{Metode Penelitian}

a) Jenis Penelitian

Adapun jenis penelitian ini didasarkan pada rumusan masalah yang akan dibahas.Metode Penelitian yang digunakan dalam penelitian ini yaitu metode deskriptif kuantitatif. Penelitian deskpriptif kuantitatif adalah salah satu jenis penelitian yang bertujuan mendeskripsikan secara sistematis, faktual, dan akurat mengenai fakta dan sifat populasi tertentu, atau mencoba menggambarkan fenomena secara detail. Jadi penelitian deskriptif kuantitatif merupakan usaha sadar dan sistematis untuk memberikan jawaban terhadap suatu masalah dan/atau mendapatkan informasi lebih mendalam dan luas terhadap suatu fenomena dengan menggunakan tahaptahap penelitian dengan pendekatan kuantitatif

\section{b) Lokasi Penelitian}

Penelitian ini mengukur tingkat mencari pengaruh secara signifikan perkembangan pengaruh pembangunan kawasan ekonomi khusus (KEK) Sorong terhadap pertumbuhan ekonomi provinsi papua barat. Penelitian ini dilakukan di Wilayah Kota Sorong Kota Sorong dengan luas wilayah $1.105 \mathrm{Km}^{2}$ terdiri dari 6 (enam ) Distrik dan 31 Kelurahan adalah pintu gerbang bagi Provinsi Papua Barat, disamping sebagai Kota persinggahan juga merupakan Kota industri, perdagangan dan jasa. Adapun luas Kota Sorong berdasarkan Luas Distrik (Kecamatan) adalah sebagai berikut : Sorong (126,85 km2),Sorong Barat $(254,15 \mathrm{~km} 2)$,Sorong Utara $(229,71 \mathrm{~km} 2)$,Sorong Timur $(158,22 \mathrm{~km} 2)$,Sorong Manoi (135,97 km2), Kepulauan Sorong $(200,10 \mathrm{~km} 2)$ jumlah penduduk kota ini bertambah cukup signifakan menjadi 239.815 jiwa (laki-laki 125.015 jiwa dan perempuan 114.800 jiwa) Perbandingan laki-laki dan perempuan atau sex ratio di Kota Sorong adalah sebesar 110,45 persen.

Dari enam distrik yang ada di Kota Sorong, angka Sex Ratio tertinggi berada di Distrik Sorong Timur yaitu sebesar 114,97 persen.Laju pertumbuhan penduduk Kota Sorong sebesar 7,02 persen per tahun. Distrik yang laju pertumbuhan penduduknya tertinggi adalah Distrik sorong Timur yakni 14,07 persen dan yang terendah adalah Distrik Sorong Kepulauan yakni sebesar 3,54 persen.Dengan Luas wilayah $1.105 \mathrm{~km}^{2}$ yang didiami penduduk 239.815 jiwa, maka rata-rata tingkat kepadatan penduduk Kota Sorong adalah sebesar 217,03 jiwa/ $\mathrm{km}^{2}$ Untuk menjawab rumusan masalah dalam penelitian ini digunakan alat analisis terkait.

c) Analisis Data

1. Rumusan masalah pertama dalam penelitian ini yaitu bagaimana Pembangunan Kawasan Ekonomi Khusus (KEK) SorongTerhadap Pertumbuhan Ekonomi Provinsi Papua Barat Sehingga alat analisis dalam penelitian ini yaitu menggunakan Alat analisis yang dipakai untuk menjawab tujuan pertama adalah Analisis LocationQuotient (LQ) dengan rumus (Putra, 2011: 163):

$\mathrm{LQ}=(\mathrm{Xir} / \mathrm{Xr}) /(\mathrm{Xin} / \mathrm{Xn})$.

Dimana : LQ>1, adalah sektor komoditas (unggulan); $\mathrm{LQ}<1$, artinya bukan sektor komoditas (defisit); $\mathrm{LQ}=0$, artinya sektor hanya cukup untuk memenuhi kebutuhan daerah itu sendiri.

Xir adalah sektor i di daerah; Xr adalah jumlah seluruh sektor di daerah; Xin adalah sektor i di nasional; Xn adalah jumlah seluruh sektor nasional.

2. Rumusan masalah kedua dalam penelitian ini yaitu adakah pengaruh secara signifikan Pembanguan Kawasan EkonomiKhusus (KEK) SorongTerhadap Pertumbuhan Ekonomi Provinsi Papua Barat. Sehingga alat analisis dalam penelitian ini yaitu menggunakan analisis regresi linier berganda yaitu hubungan secara linier antara dua atau lebih variabel independen $(\mathrm{X} 1, \mathrm{X} 2, \ldots, \mathrm{Xn})$ dengan variabel dependen (Y). Analisis ini untuk mengetahui arah hubungan antara variabel independen dengan variabel dependen apakah masing-masing variabel independen berhubungan positif atau negatif dan untuk memprediksi nilai dari variabel dependen apabila nilai variabel independen mengalami kenaikan atau penurunan . Dalam analisis regresi linear berganda, pengaruh satu variabel bebas terhadap variabel terikat dapat dibuat persamaan sebagai berikut

$$
\mathrm{Y}^{\prime}=\mathrm{a}+\mathrm{b} 1 \mathrm{X} 1+\mathrm{b} 2 \mathrm{X} 2+\ldots .+\mathrm{bnXn}
$$

Keterangan : 
$\mathrm{Y}^{\prime}=$ Variabel dependen (nilai yang diprediksikan)

$\mathrm{X} 1$ dan $\mathrm{X} 2$ = Variabel independen

$\mathrm{a}=$ Konstanta (nilai $\mathrm{Y}^{\prime}$ apabila X1, X2 ....Xn $=0$ )

$\mathrm{b}=$ Koefisien regresi (nilai peningkatan ataupun penurunan)

Konsep Dasar Analisis Regresi Linear Berganda

Adapun beberapa konsep dasar dalam merumuskan tujuan analisis regresi linear berganda, sebagai berikut;

1) Analisis regresi linear berganda bertujuan untuk mengetahui ada atau tidaknya pengaruh dua atau lebih variabel bebas $(\mathrm{X})$ terhadap variabel terikat (Y).

2) Uji t bertujuan untuk mengetahui ada atau tidaknya pengaruh parsial (sendiri) yang diberikan variabel bebas $(\mathrm{X})$ terhadap variabel terikat $(\mathrm{Y})$.

3) Uji $F$ bertujuan untuk mnegetahui ada atau tidaknya pengaruh simultan (bersama-sama) yang diberikan variabel bebas $(\mathrm{X})$ terhadap variabel terikat (Y).

4) Koefisien diterminasi berfungsi untuk mengetahui berapa persen pengaruh yang diberikan variabel $\mathrm{X}$ secara simultan terhadap variabel $\mathrm{Y}$.

\section{Hasil dan Pembahasan}

Hasil dan pembahasan dalam penelitian ini menguraikan tentang pegaruh pembangunan kawasan ekonomi khusus Sorong terhadap pertumbuhan ekonomi Provinsi Papua Barat yakni sebagai berikut. Pembahasan tersebut dijabarkan sebagai berikut:

1. Analisis Pembangunan Kawasan Ekonomi Khusus

Sorong Terhadap Perekonomian Papua Barat

Hasil analisis dalam menjawab rumusan masalah dalam penelitian ini dapat dilihat pada Tabel 1, Tabel 2 dan Tabel 3.

Seluruh sektor ekonomi (Tabel 1) pada seluruh kabupaten mengalami pertambahan nilai, kecuali sektor pertambangan di Raja Ampat yang mengalami penurunan nilai PDRB, kondisi ini sangat relevan dengan upaya mendorong wilayah raja ampat sebagai kawasan konservasi laut dengan sektor andalan adalah pariwisata.

Struktur ekonomi (Tabel 2) yang mengalami pertumbuhan sebagian besar adalah sektor ekonomi konsumtif. Dalam rangka mendorong pengembangan wilayah maka harus ada upaya pengembangna sektor produksi agar memberikan multiplier efek. Pengembangan KEK Sorong diharapkan akan menjadi jembatan untuk memperkuat peran sektor ekonomi yang sifatnya produktif pada wilayah sekitarnya.

Analisis Lq (Tabel 3) menunjukkan bahwa:

a. Sektor pertanian, kehutanan dan perikanan pada wilayah pengaruh dalam kurun waktu 2010-2016 secara umum konsisten menjadi sektor basis

b. Sektor administrasi pemerintahan, pertahanan dan jaminan social wajib pada wilayah pengaruh dalam kurun waktu 2010-2016 secara umum konsisten menjadi sektor basis

2. Analisis pengaruh Pembanguan Kawasan Ekonomi Khusus (KEK) SorongTerhadap Pertumbuhan Ekonomi Provinsi Papua Barat.

Untuk menjawab rumusan masalah kedua, digunakan alat analisis regresi berganda yang merupakan pengembangan lebih lanjut dari analisis regresi sederhana. Sering sekali dalam kehidupan sehari-hari terdapat suatu fenomena kehidupan masyarakat yang bersifat kompleks, sehingga tidak cukup untuk menjelaskan suatu kejadian hanya berdasarkan variabel penjelas tunggal atau hanya satu variabel saja. Maka dalam penelitian ini untuk mengetahui ada atau tidaknya pengaruh dua atau lebih variabel bebas yaitu (X) terhadap variabel terikat (Y) sehingga digunakan analisis Regresi Linear Berganda. Secara umum alat analisis hanya sebuah alat, sehingga interpretasi dari hasil tersebut akan dijabarkan oleh peneliti lebih lanjut. Untuk lebih jelasnya sebagaimana pada pembahasan berikut;

a. Analisis keakuratan data

Berdasarkan tampilan output chart di bawah, maka dapat dilihat grafik histrogram maupun grafik plot. Dimana grafik histrogram memberikan pola distribusi yang melenceng kekanan yang artinya adalah data berdistirbusi normal. Selanjutnya, pada gambar P-Plot terlihat titik titik mengikut dan mendekati garis diagonalnya sehingga dapat disimpulkan bahwa model regresi memenuhi asumsi normalitas. Untuk menguji apakah dalam model regresi, variabel residu memiliki distribusi normal atau tidak, dilakukan pengambilan keputusan uji normalitas adalah sebagai berikut;

a) Data berdistribusi normal, jika nilai sig. ( signifikansi) $>0,05$

b) Data berdistribusi tidak normal, jika nilai sig. (signifikansi) $<0,05$

Berdasarkan uji normalitas dengan KolmogorovSmirnov Test diperoleh nilai KSZ sebesar 0,877 dan Asymp.sig. sebesar 0,425 lebih besar besar dari 0,05, maka dapat disimpulkan data berdistribusi normal. Untuk lebih jelasnya terkait uji normalitas, sebagai berikut: Histogram

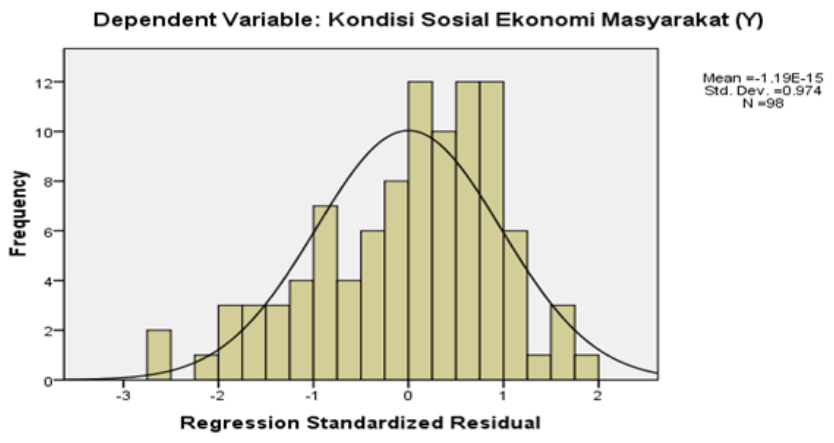

Gambar 1. Histrogram pada hasil Pengujian Kurva Uji t Normal P-P Plot of Regression Standardized Residual

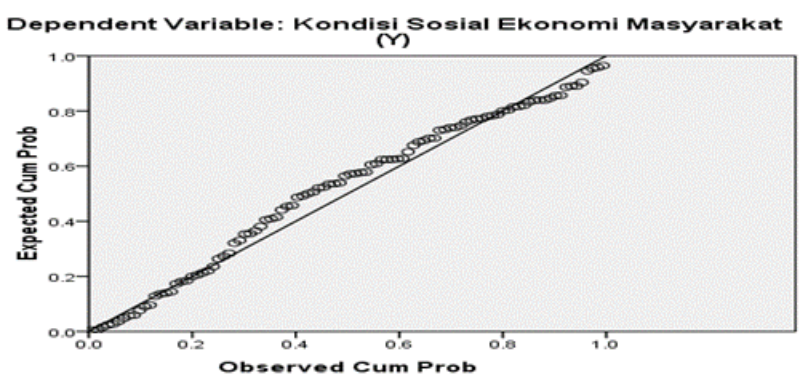

Gambar 2. Grafik Normal P-P Plot Standar Regresi Residu 
Tabel 4 Uji normalitas dengan Kolmogorov-Smirnov Test

\begin{tabular}{l|l|r}
\hline \multicolumn{2}{c}{ One-Sample Kolmogorov-Smirnov Test } \\
\hline \multicolumn{2}{|c|}{} & $\begin{array}{c}\text { Unstandardized } \\
\text { Residual }\end{array}$ \\
\hline $\mathrm{N}$ & & 98 \\
\hline \multirow{2}{*}{ Normal Parameters ${ }^{\mathrm{a}, \mathrm{b}}$} & Mean & .0000000 \\
\cline { 2 - 3 } & Std. Deviation & .089 \\
\hline Most Extreme Differences & Absolute & .055 \\
\cline { 2 - 3 } & Positive & -.089 \\
\cline { 2 - 3 } & Negative & .877 \\
\hline Kolmogorov-Smirnov Z & & .425 \\
\hline Asymp. Sig. (2-tailed) & & \\
\hline a. Test distribution is Normal. & & \\
\hline b. Calculated from data. & & \\
\hline
\end{tabular}

Sumber : Hasil Analisis Penelitian, 2019

b. Analisis faktor yang mempengaruhi Pembangunan Kawasan Ekonomi Khusus Sorong Terhadap Pertumbuhan Ekonomi Papua Barat

1. Uji Koefisien Regresi Secara Parsial (Uji t)

Uji (uji parsial) ini di lakukan untuk mengetahui apakah fariabel predicator Pelayanan Jasa (X1), Industri (X2), tenaga kerja (x3), model pelayanan (x4), ekspor (x5), perdagangan (x6) secara parsial (sendiri-sendiri) berpengaruh seacara signifkan terhadap variabel kriterium (Y).signifikan berarti hubungan yang terjadi dapat untuk populasi ( dapat di generilisasikan) sebelum melakukan uji t,perlu untuk menentkan terlebih dahulu nilai-nilai berikut ini:

- Menentukan taraf signifikansi

Tarafs signifikansi menggunakan $\alpha=10 \%$ (signifikansi $10 \%$ atau 0,1 adalah ukuran yang sering di gunakan dalam penelitian dengan populasi yang besar

- Menetukan t table

Dengan menggunakan tingkat keyakinan $90 \%, \alpha=10 \%$ atau 0,1,nilai dfresidual (n-k-1) atau 100-6-1= 93 (n adalah jumlah data dan $\mathrm{k}$ adalah jumlah variabel predicator)

- Untuk menghitung nilai t menggunakan bantuan excel dengan memasukan rumus sebagai berikut

$=$ TINV (probability;deg_freedom)

Keterangan : -probability : probabilitas $(0,10)$ deg_freedom : derajat kebebasan (93) Hasil di peroleh untuk table sebesar

1). Faktor Pelayanan Jasa (X1)

Berdasarkan hasil hasil analisis pada kolom t 4.17 di atas dapat di ketahui nilai thitung Pelayanan Jasa sebesar 8,782.untuk melakuakan uji t tahapnya sebagai berikut :

a. Merumuskan Hipotesa

Rumusn hipotesis berdasarkan pendekatan teoritis seperti yang telah di bahas di atas pada bab II adalah sebagai berikut:

H1 : Pelayanan Jasa Berpengaruh secara signifikan terhadap Pertumbuhan Ekonomi Provinsi Papua Barat

b. Menetukan thitung

Berdasarkan analisis di peroleh thitng sebesar 8,782

c. Kriteria Penguian

- $\quad$ H1 terima jika thitung $>$ ttabel

- $\quad H 1$ ditolak jika thitung <ttabel

d. Membanding thitung dengan ttabel

Nilai thitung $>$ ttabel $(8,782>0,005)$ maka H1 di terima.

e. Kesimpulan

karena thitung >ttabel $(8,782>0,005)$ maka $\mathrm{H} 1$ di terima.Artinya pada perhitungan ini dapat di simpulkan
Pelayanan Jasa berpengaruh signifikan dalam pertumbuhan ekonomi di provinsi papua barat

2). Faktor Industri (X2)

Berdasarkan hasil hasil analisis pada kolom t 4.17 di atas dapat di ketahui nilai thitung Industri sebesar -2,223.untuk melakuakan uji t tahapnya sebagai berikut :

a. Merumuskan Hipotesa

Rumusn hipotesis berdasarkan pendekatan teoritis seperti yang telah di bahas di atas pada bab II adalah sebagai berikut:

H2 : Industri tidak Berpengaruh secara signifikan terhadap Pertumbuhan Ekonomi Provinsi Papua Barat

b. Menetukan thitung

Berdasarkan analisis di peroleh thitng sebesar 2,223.Kriteria Penguian

- $\mathrm{H} 2$ terima jika thitung $>$ ttabel

- $\mathrm{H} 2$ ditolak jika thitung $<$ ttabel

c. Membanding thitung dengan ttabel

Nilai thitung $>$ ttabel $(-2,223<0,005)$ maka $\mathrm{H} 2$ di tolak.

d. Kesimpulan

karena thitung $>$ ttabel $(-2,223<0,005)$ maka $\mathrm{H} 2$ di terima.Artinya pada perhitungan ini dapat di simpulkan industri tidak berpengaruh signifikan dalam pertumbuhan ekonomi di provinsi papua barat

3) Tenaga kerja (x3)

Berdasarkan hasil hasil analisis pada kolom t 4.17 di atas dapat di ketahui nilai thitung Industri sebesar 0,009.untuk melakuakan uji t tahapnya sebagai berikut :

a. Merumuskan Hipotesa

Rumusn hipotesis berdasarkan pendekatan teoritis seperti yang telah di bahas di atas pada bab II adalah sebagai berikut:

H3 : Tenaga kerja Berpengaruh secara signifikan terhadap Pertumbuhan Ekonomi Provinsi Papua Barat

b. Menetukan thitung

Berdasarkan analisis di peroleh thitng sebesar 0,009.Kriteria Pengujian

-H3 terima jika thitung $>$ ttabel

$\bullet$ H3 ditolak jika thitung $<$ ttabel

c. Membanding thitung dengan ttabel

Nilai thitung >ttabel $(0,009>0,005)$ maka H3 di terima.

d. Kesimpulan

karena thitung >ttabel $(0,009 .>0,005)$ maka H3 di terima.Artinya pada perhitungan ini dapat di simpulkan tenaga kerja berpengaruh signifikan dalam pertumbuhan ekonomi di provinsi papua barat

4) Model pelayanan $(x 4)$

Berdasarkan hasil hasil analisis pada kolom t 4.17 di atas dapat di ketahui nilai thitung Industri sebesar -0,267.untuk melakuakan uji t tahapnya sebagai berikut :

a. Merumuskan Hipotesa

Rumusn hipotesis berdasarkan pendekatan teoritis seperti yang telah di bahas di atas pada bab II adalah sebagai berikut:

H4 : model pelayanan tidak Berpengaruh secara signifikan terhadap Pertumbuhan Ekonomi Provinsi Papua Barat

b. Menetukan thitung

Berdasarkan analisis di peroleh thitng sebesar 0,267.Kriteria Pengujian

$\mathrm{H} 4$ terima jika thitung $>$ ttabel 
H4 ditolak jika thitung<ttabel

c. Membanding thitung dengan ttabel

Nilai thitung $>$ ttabel $(-0,267<0,005)$ maka H4 di tolak.

d. Kesimpulan

karena thitung $>$ ttabel $(-0,267 .<0,005)$ maka $\mathrm{H} 4$ di terima.Artinya pada perhitungan ini dapat di simpulkan model pelayanan tidak berpengaruh signifikan dalam pertumbuhan ekonomi di provinsi papua barat

H5 : Perdagangan Berpengaruh secara signifikan terhadap Pertumbuhan Ekonomi Provinsi Papua Barat

5). Menetukan thitung

Berdasarkan analisis di peroleh thitng sebesar 0,009.Kriteria Pengujian

- H5 terima jika thitung $>$ ttabel

- H5 ditolak jika thitung<ttabel

a. Membanding thitung dengan ttabel

Nilai thitung $>$ ttabel $(1,571>0,005)$ maka $\mathrm{H} 5$ di terima.

b. Kesimpulan

karena thitung >ttabel ( 1,571.>0,005) maka H5 di terima.Artinya pada perhitungan ini dapat di simpulkan tenaga kerja berpengaruh signifikan dalam pertumbuhan ekonomi di provinsi papua barat

6) Perdagangan (x6)

Berdasarkan hasil hasil analisis pada kolom t 4.17 di atas dapat di ketahui nilai thitung Industri sebesar,078.untuk melakuakan uji t tahapnya sebagai berikut :

a. Merumuskan Hipotesa

Rumusn hipotesis berdasarkan pendekatan teoritis seperti yang telah di bahas di atas pada bab II adalah sebagai berikut :

H6 : Perdagangan Berpengaruh secara signifikan terhadap Pertumbuhan Ekonomi Provinsi Papua Barat

b. Menetukan thitung

Berdasarkan analisis di peroleh thitng sebesar 0,009.Kriteria Pengujian

- H6 terima jika thitung>ttabel

- H6 ditolak jika thitung $<$ ttabel

c. Membanding thitung dengan ttabel

Nilai thitung $>$ ttabel $(078>0,005)$ maka H6 di terima.

d. Kesimpulan

karena thitung >ttabel ( 078.>0,005) maka H6 di terima.Artinya pada perhitungan ini dapat di simpulkan tenaga kerja berpengaruh signifikan dalam pertumbuhan ekonomi di provinsi papua barat

Berdasarkan dasar pengambilan keputusan dapat disimpulkan bahwa X1, X3,X5,X6 diterima yang berarti terdapat pengaruh terhadap Y sedangkan X2, X4 ditolak yang berarti tidak terdapat pengaruh terhadap $\mathrm{Y}$.

a. Hasil Interpretasi Kofisien Korelasi Ganda

Kofisien Korelasi dalam regresi linier berganda di gunakan untuk mengetahui hubungan antara variabel predicator Pelayanan Jasa (X1), Industri (X2), tenaga kerja (x3), model pelayanan (x4), ekspor (x5), perdagangan (x6) secara parsial berpengaruh terhadap variabel kriterium (Y).Koefisien ini menunjukan seberapa besar hubungan yang terjadi antara variabel predicator (X1,X2,X3,X4,X5,X6) secara sendiri-diri terhadap variabel kriterium (Y).Nilai $\mathrm{R}$ berkisar 0 sampai 1,nilai semakin mendekati lberarti hubungan yang terjadi semakin kuat ,sebaliknya nilai semakin mendekati 0 maka hubunga yang terjadi semakin lemah

Menurut Akbar (2011:201) pedoman untuk memberikan interpertasi koefisien korelasi sebagai berikut $\mathrm{Kk}=0$ tidak berkorelasi
$\mathrm{Kk}=0,001-0,200$ korelasi sangat rendah / lemah

$\mathrm{Kk}=0,201-0,400$ korelasi rendah / lemah

$\mathrm{Kk}=0,401-0,600$ korelasi agak rendah $/$ lemah

$\mathrm{Kk}=0,601-0,800$ korelasi cukup tinggi / kuat

$\mathrm{Kk}=0,801-0,999$ korelasi tinggi / kuat

$\mathrm{Kk}=1$, korelasi sangat tinggi / kuat,sempurna

1. Faktor Pelayanan Jasa (X1)

Dari hasil analisis koefisen regresi pada table 4.17 di atas,dalam kolom correlations-partial di peroleh angka $\mathrm{R}$ untuk variabel Pelayanan Jasa.832 Nilai tersebut menunjukan bahwa terjadi hubungan yang kuat antara Pelayanan Jasa (X1).Angka positif searah mengartiakan bahwa jika nilai Pelayanan Jasa meningkat maka pertumbuhan ekonomi akan mengalami peningkatan.

2. Faktor Industri (X2)

Dari hasil analisis koefisen regresi pada table 4.17 di atas,dalam kolom correlations-partial di peroleh angka $\mathrm{R}$ untuk variabel industry -.010 Nilai tersebut menunjukan bahwa terjadi hubungan yang kuat antara industri (X2).Angka negatif tidak searah mengartiakan bahwa jika nilai Industri meningkat maka pertumbuhan ekonomi akan mengalami penurunan.

3. Tenaga kerja (X3)

4. Dari hasil analisis koefisen regresi pada table $4.17 \mathrm{di}$ atas,dalam kolom correlations-partial di peroleh angka $\mathrm{R}$ untuk variabel tenaga kerja .428 Nilai tersebut menunjukan bahwa terjadi hubungan yang kuat antara tenaga kerja (X3).Angka positif searah mengartiakan bahwa jika nilai tenaga kerja meningkat maka pertumbuhan ekonomi akan mengalami peningkatan.

5. Model Pelayanan (X4)

Dari hasil analisis koefisen regresi pada table 4.17 di atas,dalam kolom correlations-partial di peroleh angka $\mathrm{R}$ untuk variabel model pelayanan -.032 Nilai tersebut menunjukan bahwa terjadi hubungan yang lemah antara model pelayanan (X4).Angka negatif tidak searah mengartiakan bahwa jika nilai model pelayanan meningkat maka pertumbuhan ekonomi akan mengalami penurunan.

6. Perdagangan(X5)

Dari hasil analisis koefisen regresi pada table 4.17 di atas,dalam kolom correlations-partial di peroleh angka $\mathrm{R}$ untuk variabel Perdagangan . 446 Nilai tersebut menunjukan bahwa terjadi hubungan yang kuat antara perdagangan (X5).Angka positif searah mengartiakan bahwa jika nilai perdagangn meningkat maka pertumbuhan ekonomi akan mengalami peningkatan.

7. Perdagangan(X6)

Dari hasil analisis koefisen regresi pada table 4.17 di atas,dalam kolom correlations-partial di peroleh angka R untuk variabel Perdagangan .629 Nilai tersebut menunjukan bahwa terjadi hubungan yang kuat antara perdagangan (X6).Angka positif searah mengartiakan bahwa jika nilai perdagangn meningkat maka pertumbuhan ekonomi akan mengalami peningkatan.

Berdasarkan hasil analisis LQ, dapat disimpulkan bahwa Sektor pertanian, kehutanan dan perikanan pada wilayah pengaruh dalam kurun waktu 2010-2016 secara umum konsisten menjadi sektor basis Sektor administrasi pemerintahan, pertahanan dan jaminan social wajib pada wilayah pengaruh dalam kurun waktu 2010-2016 sehingga dapat meningkat perekonomian di wilayah di sekitarnya. 
Berdasarkan hasil analisis Faktor pelayanan jasa ternyata memiliki pengaruh signifikan dalam pertumbuhan eknomi di Kawasan Ekonomi Khusus sorong porovinsi Papua Barat.Hal ini sesuai sesuai dengan hasil wawancara terbuka terhadap sebagian besar responden.mereka menjelaskan bahwa pelayanan jasa dikota sorong sangat baik sehingga dapat membntu mereka dalam menjalan aktifitas mereka karena sarana prasarana penunjang sangat mendukung aktifitas masyarakat di papua barat dalam kehidupan sehri-hari.

Faktor ke dua ternyata memiliki pengaruh signifikan dalam pertumbuhan eknomi Kawasan Ekonomi Khusus sorong porovinsi Papua Barat.Hal ini sesuai sesuai dengan hasil wawancara terbuka terhadap sebagian besar responden.mereka menjelaskan bahwa model pelayanan dikota sorong sangat baik sehingga dapat membntu mereka dalam menjalan aktifitas mereka karena di berikan kemudahan dalama mendukung aktifitas masyarakat di papua barat dalam kehidupan sehri-hari.

Faktor ketiga ternyata memiliki pengaruh signifikan dalam pertumbuhan eknomi Kawasan Ekonomi Khusus sorong porovinsi Papua Barat.Hal ini sesuai sesuai dengan hasil wawancara terbuka terhadap sebagian besar responden.mereka menjelaskan bahwa Perdaganagan dikota sorong sangat baik sehingga dapat membantu mereka dalam menjalan aktifitas jual beli mereka karena di berikan kemudahan masyarakat dalam menjalan aktivitas jual beli barang di papua barat dalam kehidupan seharihari.

Faktor keempat ternyata memiliki pengaruh signifikan dalam pertumbuhan eknomi Kawasan Ekonomi Khusus sorong porovinsi Papua Barat.Hal ini sesuai sesuai dengan hasil wawancara terbuka terhadap sebagian besar responden.mereka menjelaskan bahwa eksport dikota sorong sangat baik sehingga dapat membantu mereka dalam menjalan aktifitas perdagangan sehingga hasil-hasil bumi bias di jual keluar daerah melalui eksport di Kota Sorong.

\section{Kesimpulan dan Saran}

Hasil penelitian dapat disimpulkan bahwa indikator yang paling mempengaruhi terhadap variabel Hambatan Samping pada ruas Jalan Letnan Jenderal Hertasning adalah kendaraan yang melambat sedangkan kendaraan masuk atau keluar merupakan kontribusi paling rendah. Adapun keadaan hambatan samping tertinggi terjadi pada waktu akhir pekan (Hari Minggu) pada segmen IV Arah dari Jl. Letjend Hertasning ke Jl. Tun Abdul Razak. Diantara keempat segmen lokasi penelitian Jalan Letnan Jenderal pada Segmen IV berkontribusi sangat tinggi terhadap volume lalu lintas sebesar 50,93\% terhadap volume lalulintas kendaraan dengan kondisi Derajat kejenuhan lebih dari 0,81 dengan kategori kelas sangat tinggi. Kompleksitas guna lahan berbeda-beda di tiap segmen lokasi penelitian ruas Jalan Letnan Jenderal Hertasning dengan fungsi Permukiman, Perdagangan, Perkantoran, Sekolah, hingga Peribadatan dengan tingkat sederhana hingga kompleks. Adapun segmen I memiliki guna lahan yang sangat kompleks dan segmen IV yang paling sederhana.

\section{Daftar Pustaka}

Almeida, B. (2005). A GIS Assessment of Urban Sprawl in Richmond, Virginia. Blacksburg. Virginia Polytechnic Institute and State University.

Bintarto, R. (1983). Interkasi Kota - Desa dan Permasalahannya. Yogyakarta: Ghalia Indonesia.

Departemen Pekerjaan Umum., 1997, Manual Kapasitas Jalan Indonesia (MKJI), Direktorat Jenderal Bina Marga dan Departemen Pekerjaan Umum Jakarta.

Karakayaci, Z. (2017). The concept of urban sprawl and its causes. The Journal of International Social Research, $9(45), \quad 815-818$. doi:10.17719/jisr.20164520658.

Mahmud, A., \& Achide, A. S. (2012). Analysis of land use/land cover changes to monitor urban sprawl in keffinigeria. Environmental Research Journal, 6(2), 130-135.

Nasaruddin, M. M., Manaf, M., \& Saleh, H. (2020). Pengaruh Pengembangan Kawasan Perumahan Terhadap Sosial Ekonomi dan Minimalisasi Gejala Urban Sprawl. Urban and Regional Studies Journal, 2(1), 15-24.

Slaev, Aleksandar, D., \& Nikiforov, I. (2013). Factors of urban sprawl in Bulgaria. SPATIUM International Review, 29, 22-29.

Soetomo, S. (2013). Urbanisasi dan Morfologi, Proses perkembangan peradaban \& wadah ruang: Menuju ruang kehidupan yang manusiawi. Yogyakarta: Graha Ilmu.

Sudhira, H. ., \& Ramachandra, T. . (2007). Characterising urban sprawl from remote sensing data and using landscape metrics. In 10th International Conference on Computers in Urban Planning and Urban Management. Brazil: Iguassu Falls.

Yunus, H. S. (2008). Dinamika Wilayah Peri Urban Determinan Masa Depan Kota. Yogyakarta: Pusataka Pelajar 
Tabel 1 Perkembangan PDRB Kota/Kabupaten Wilayah Pengaruh KEK Sorong dan Sekitarnya ADHK

Tahun $2010-2016$

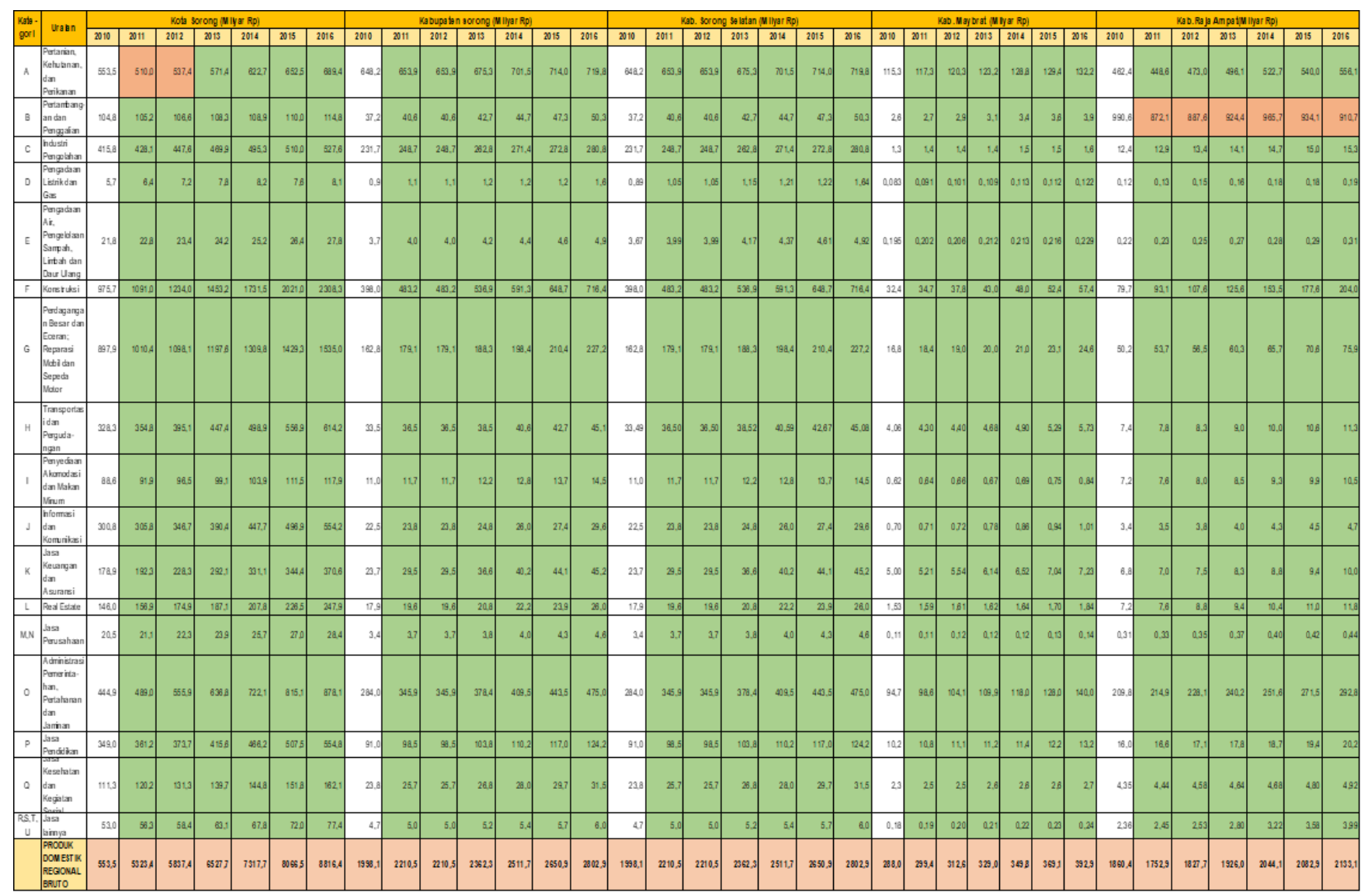

Sumber: PDRB Kota Sorong

Tabel 2 Perkembangan Struktur Perekonomian Kota/Kabupaten Wilayah Pengaruh KEK Sorong dan Sekitarnya ADHK Tahun 2010-2016

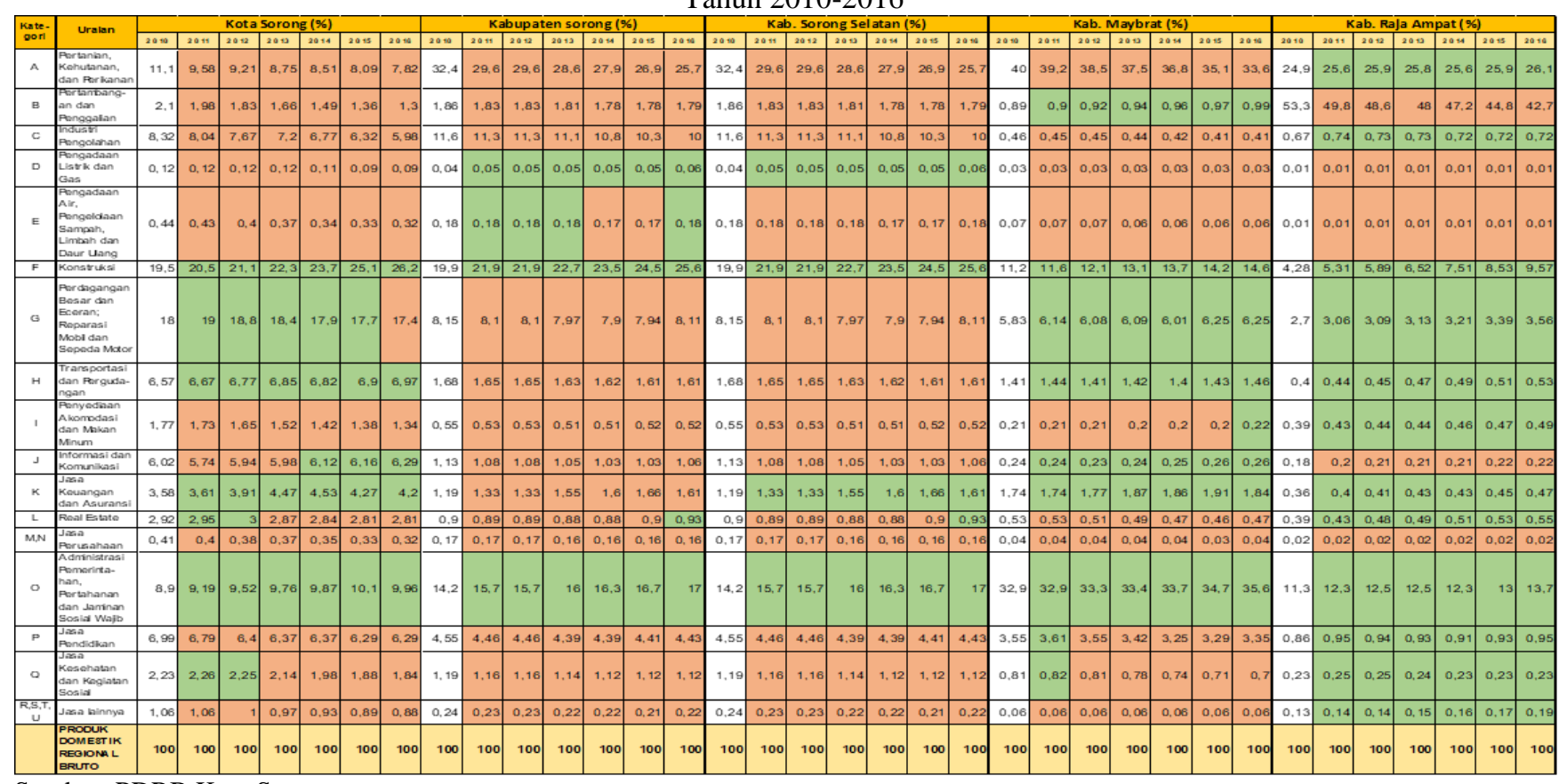

Sumber: PDRB Kota Sorong 
Tabel 3 Perkembangan Perekonomian Kabupaten/Kota di KEK Sorong dan Sekitarnya

\begin{tabular}{|c|c|c|c|c|c|c|c|}
\hline \multirow{2}{*}{ S ektor E konomi } & \multicolumn{7}{|c|}{ Ha sil Nilai LQ Kabupaten Sorong } \\
\hline & 2010 & 2011 & 2012 & 2013 & 2014 & 2015 & 2016 \\
\hline Pertanian, Kehutanan, dan Perikanan & 2,74 & 2,77 & 2,75 & 2,68 & 2,63 & 2,57 & 2,56 \\
\hline Pertambangan dan Penggalian & 0,07 & 0,07 & 0,08 & 0,08 & 0,08 & 0.08 & 0,09 \\
\hline Industri Pengolahan & 0,35 & 0,34 & 0,34 & 0,34 & 0,33 & 0,32 & 0.32 \\
\hline Pengada a n Listrik, Gas & 1,39 & 1,38 & 1,27 & 1,28 & 1,29 & 1,31 & 1,67 \\
\hline Pengadaan Air, Pengelolaan Sampah, Limbah dan Daur Ulang & 1,59 & 1,61 & 1,58 & 1,59 & 1,57 & 1.55 & 1,58 \\
\hline Konstruksi & 2,57 & 2,52 & 2,31 & 2,23 & 2,16 & 2,14 & 2,13 \\
\hline Perdagangan Besar dan Eceran, dan Reparasi Mobil dan Sepeda Motor & 1,63 & 1,49 & 1.46 & 1.44 & 1.39 & 1,36 & 1.33 \\
\hline Transportasi dan Pergudangan & 0.94 & 0.90 & 0,82 & 0,77 & 0,71 & 0,68 & 0,68 \\
\hline Penyediaan Akomodasi dan Makan Minum & 1,09 & 1,06 & 1.04 & 1,04 & 1,03 & 1,02 & 0,99 \\
\hline Informasi dan Komunika si & 0,80 & 0,79 & 0,70 & 0,67 & 0,62 & 0,60 & 0,59 \\
\hline Jasa Keuangan dan Asuransi & 1,24 & 1,34 & 1.19 & 1.19 & 1,17 & 1,17 & 1,16 \\
\hline Real Estate & 0,98 & 0,94 & 0,88 & 0,87 & 0,84 & 0,83 & 0.83 \\
\hline Jasa Perusahaan & 1,69 & 1,68 & 1.68 & 1,62 & 1,55 & 1.52 & 1.54 \\
\hline Admi ni strasi Pemerintahan, Pertahanan dan Jaminan Sosial Wajib & 2,15 & 2,23 & 2,06 & 2,06 & 2,05 & 2,02 & 1,97 \\
\hline Jasa Pendidikan & 2,07 & 2,04 & 2,02 & 1,94 & 1,85 & 1,81 & 1.79 \\
\hline Jasa Kesehatan dan Kegiatan Sosial & 1,67 & 1,56 & 1,51 & 1,57 & 1,56 & 1,51 & 1,49 \\
\hline Jasa lainnya & 0.95 & 0.92 & 0.92 & 0,88 & 0.85 & 0.82 & 0,81 \\
\hline Sektor Ekonomi & & & Hasil Nila & LQ Kota & orong & & \\
\hline 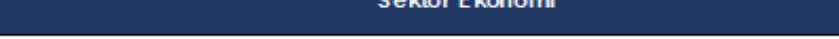 & 2010 & 2011 & 2012 & 2013 & 2014 & 2015 & 2016 \\
\hline Pertanian, Kehutanan, dan Perikanan & 0,94 & 0,90 & 0,85 & 0,82 & 0,80 & 0,77 & 0,78 \\
\hline Pertambangan dan Penggalian & 0,08 & 0,08 & 0,08 & 0,07 & 0,07 & 0,06 & 0,06 \\
\hline Industri Pengolahan & 0,25 & 0,24 & 0,23 & 0,22 & 0,21 & 0,20 & 0,19 \\
\hline Pengadaan Listrik, Gas & 3,60 & 3,49 & 3,29 & 3,16 & 3,01 & 2,69 & 2,60 \\
\hline Pengadaan Air, Pengelolaan Sampah, Limbah dan Daur Ulang & 3,77 & 3,81 & 3,52 & 3,33 & 3,10 & 2,92 & 2,84 \\
\hline Konstruksi & 2,52 & 2,36 & 2,23 & 2,18 & 2,17 & 2,19 & 2,18 \\
\hline Perdagangan Besar dan Eceran, dan Reparasi Mobil dan Sepeda Motor & 3,60 & 3,48 & 3,40 & 3,31 & 3,15 & 3,04 & 2,86 \\
\hline Transportasi dan Pergudangan & 3,69 & 3,64 & 3,37 & 3,25 & 3,01 & 2,93 & 2,86 \\
\hline Penyediaan Akomodasi dan Makan Minum & 3,52 & 3,46 & 3,26 & 3,08 & 2,87 & 2,73 & 2,56 \\
\hline Informasi dan Komunika si & 4,28 & 4,19 & 3,85 & 3,81 & 3,69 & 3,60 & 3,49 \\
\hline Jasa Keuangan dan Asuransi & 3,74 & 3,61 & 3,47 & 3,44 & 3,32 & 3,00 & 3,02 \\
\hline Real Estate & 3,20 & 3,13 & 2,92 & 2,83 & 2,70 & 2,59 & 2,50 \\
\hline Jasa Perusahaan & 4,09 & 4,02 & 3,81 & 3,64 & 3,41 & 3,16 & 3,02 \\
\hline Administrasi Pemerintahan, Pertahanan dan Jaminan Sosial Wajib & 1,34 & 1,31 & 1,25 & 1,26 & 1,24 & 1,22 & 1,16 \\
\hline Jasa Pendidikan & 3,18 & 3,10 & 2,90 & 2,81 & 2,68 & 2,58 & 2,54 \\
\hline Jasa Kesehatan dan Kegiatan Sosial & 3,11 & 3,03 & 2,92 & 2,95 & 2,76 & 2,53 & 2,43 \\
\hline Jasa lainnya & 4,28 & 4,27 & 4,05 & 3,85 & 3,64 & 3,43 & 3,28 \\
\hline
\end{tabular}

Sumber: PDRB Kota Sorong

Tabel 5 Hasil Analisis Regresi Ganda Coefficientsa

\begin{tabular}{|c|c|c|c|c|c|c|c|c|c|}
\hline \multicolumn{10}{|c|}{ Coefficients $^{\mathrm{a}}$} \\
\hline & \multirow{2}{*}{ Model } & \multicolumn{2}{|c|}{$\begin{array}{l}\text { Unstandardized } \\
\text { Coefficients }\end{array}$} & $\begin{array}{l}\text { Standardized } \\
\text { Coefficients }\end{array}$ & \multirow{2}{*}{$\mathrm{t}$} & \multirow{2}{*}{ Sig. } & \multicolumn{3}{|c|}{ Correlations } \\
\hline & & $\mathrm{B}$ & Std. Error & Beta & & & Zero-order & Partial & Part \\
\hline \multirow[t]{7}{*}{1} & (Constant) & 4,082 & 1,068 & & 3,821 &, 000 & & & \\
\hline & Pelayanan Jasa &, 715 & 081 & ,743 & 8,782 &, 000 & .862 & .832 & .197 \\
\hline & Industri &,- 227 & , 102 &,- 190 & $-2,223$ & ,029 & -.030 & -.010 & -.001 \\
\hline & Tenaga Kerja & ,001 & ,099 & ,001 & ,009 & ,993 & .032 & .428 & .024 \\
\hline & Modal Pelayanan &,- 035 & , 132 &,- 031 &,- 267 & ,790 & -.162 & -.032 & -.026 \\
\hline & Perdagangan & ,201 & 128 & ,181 & 1,571 &, 119 & .651 & .446 & .023 \\
\hline & Eksport & , 010 & , 130 & ,009 & ,078 & ,938 & .826 & .629 & .267 \\
\hline
\end{tabular}

